\title{
Resource guarding by Ptomascopus morio: Simple parental care in the Nicrophorinae (Coleoptera: Silphidae)
}

\author{
SEIZI SUZUKI ${ }^{1}$ and MASAHIRO NAGANO ${ }^{2}$ \\ ${ }^{1}$ Ecology and Systematics, Graduate School of Agriculture, Hokkaido University, Sapporo 060-8589, Japan; \\ e-mail: seizi@res.agr.hokudai.ac.jp \\ ${ }^{2}$ Echigo-Matsunoyama Museum of Natural Science, 712-2 Matsukuchi, Matsunoyama-machi, Niigata 942-1411, Japan
}

Key words. Coleoptera, Silphidae, parental care, comparative method, resource guarding, predation, Nicrophorus, Ptomascopus, Ontholestes

\begin{abstract}
Nicrophorine beetles use small vertebrate carrion for breeding resource. While Nicrophorus spp. have highly developed biparental care, no form of parental care is recorded for Ptomascopus spp. We examined two effects of resource guarding by Ptomascopus morio. The presence of parents, especially the female, reduced the number of fly larvae on chicken carrion. Parents also enhanced the survival of brood faced with predation by the rove beetle, Ontholestes gracilis. In 6 out of 20 trials, the rove beetle predators were killed by Ptomascopus morio parents. We conclude that Ptomascopus morio has a simple, and possibly primitive form of parental care.
\end{abstract}

\section{INTRODUCTION}

The evolution of parental care is a central issue in evolutionary biology. Parental care has evolved numerous times in many taxa (Clutton-Brock, 1991) and in at least 13 orders of insects (Tallamy \& Wood, 1986; Tallamy, 1994, 1999). Prime movers of parental care are rich but ephemeral resources and the threat of predation (Wilson, 1971). Parental care in insects include protection of offspring, securing resources needed by offspring and feeding offspring (Clutton-Brock, 1991; Tallamy \& Wood, 1986).

The complex biparental care of burying beetles (Silphidae: Nicrophorinae: Nicrophorus) is well known and has received considerable attention (reviewed in Eggert \& Müller, 1997; Scott, 1998). Nicrophorus exploits small vertebrate carrion as a source of food for their young. Typically a male-female pair prepares a carcass by burying it, removing hair, and rounding it into a ball (Pukowski, 1933). Eggs are laid in the soil adjacent to the carrion ball. After hatching, larvae crawl to the carrion ball where they feed on parental regurgitations.

Despite extensive study, the origin of parental care within the Nicrophorinae is still a mystery. Since all Nicrophorus species studied to date show similar parental behaviour such as burying carcasses, maintaining a nest, feeding young, and defense, parental care is likely to be a synapomorphic character in this genus (Eggert \& Müller, 1997). The comparative method has been a powerful tool in assessing the origin and evolutionary history of parental care in many insect groups (Halffter \& Edmonds, 1982; Nalepa \& Bell, 1997; Tallamy \& Schaefer, 1997; Lin et al., 2004). The comparative method could not be employed for silphid beetles, however, because no close relatives of Nicrophorus are known to show parental care.

Ptomascopus and Nicrophorus are thought to form a monophyletic group, with Ptomascopus apparently retaining more ancestral traits than Nicrophorus (Peck \& Anderson, 1985; Dobler \& Müller, 2000; Szalanski et al., 2000). Ptomascopus is reported to lack developed parental behavior (Peck, 1982; Trumbo et al., 2001). Ptomascopus exploits small vertebrate carrion, like Nicrophorus, but does not bury or round the carcass, or feed its larvae (Peck, 1982; Trumbo et al., 2001).
Trumbo et al. (2001), however, noted that Ptomascopus morio Kraatz stayed on or near carcasses even after their larvae hatched and their presence reduced competition with fly larvae. We hypothesize that this behaviour is resource guarding and may have additional positive effects on the brood. If this interpretation is correct, $P$. morio demonstrates a simple form of parental care, which may shed light on the origin of parental care in Nicrophorus. In this paper, we test (1) whether P. morio parents guard carrion and/or brood against competition from fly larvae, and (2) guard their brood against a predator.

\section{MATERIAL AND METHODS}

All Ptomascopus morio beetles were caught in Naebo Forest Park in Otaru, near Sapporo, situated in southwestern Hokkaido, northern Japan using hanging traps baited with rotten meat. For the experiments, a polyethylene container $(15 \times 15 \times 15 \mathrm{~cm})$ was half-filled with soil and $15 \mathrm{~g}$ chicken meat was placed in the center. These containers were placed in scavenger-proof cages on the forest floor.

\section{Guarding against carrion fly larvae}

To test the effectiveness of care by single male and single female beetles, male-female pairs were first established in containers with $15 \mathrm{~g}$ of chicken meat. Next, the male and female were removed and individually placed in a new container either: (1) several hours after $(\mathrm{N}=23)$; (2) after oviposition had begun $(\mathrm{N}=22)$; or $(3)$ after the larvae had hatched $(\mathrm{N}=18)$. Each male and female was provided a new carrion source $(15 \mathrm{~g}$ fresh chicken meat). When $P$. morio larvae hatched on the original carrion, half of them were carefully transferred to new carrion along with male parent and half with the female parent. Ten carrion fly larvae were also placed on the chicken meat at this time (the carrion fly larvae were collected from chicken meat exposed in the field on warm, sunny days). As a control, 10 carrion fly larvae were placed on $15 \mathrm{~g}$ of fresh chicken meat in a container without a $P$. morio adult $(\mathrm{N}=11)$. The number of fly larvae was counted two days later. 


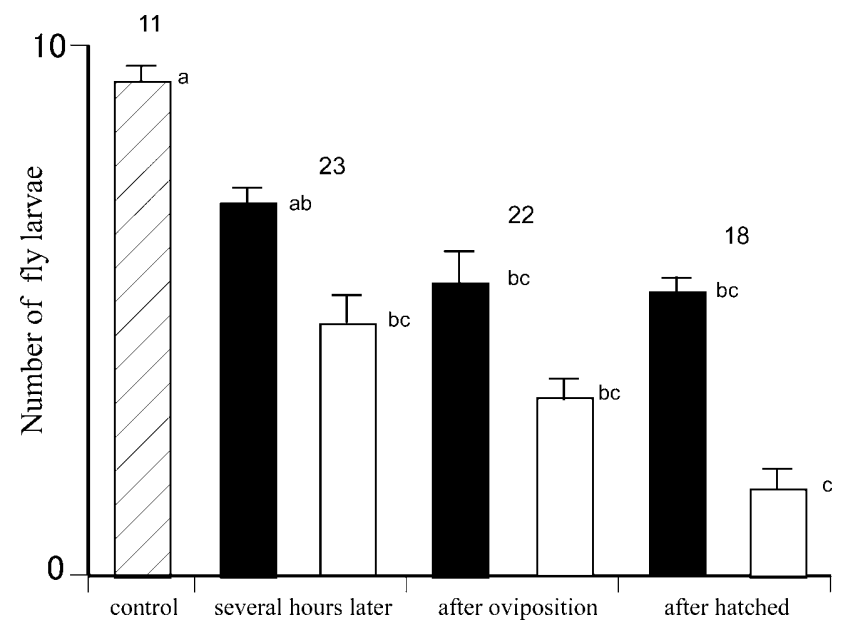

Fig. 1. Mean ( \pm SE) number of fly larvae in the control (hatched bar), in trials with the male parent (solid bars) and the female parent (open bars). Bars with the same letter are not significantly different $(\mathrm{P}<0.05$, Holm's method).

\section{Guarding against predators}

A pair of $P$. morio, along with chicken meat $(15 \mathrm{~g})$, was placed in a container and checked daily. After $P$. morio larvae were observed on the meat, both parents were either removed $(\mathrm{N}$ $=18)$, or left in the containers $(\mathrm{N}=20)$. The rove beetle, Ontholestes gracilis, which is a common species at this site (Ohara, 1995), was placed on each container at this time. To increase the hunger of the rove beetles, they were starved for 3-4 days before the experiment (rove beetles were previously fed on fly larvae). Two days after the introduction of the predator, the numbers of $P$. morio larvae were counted. Survival and injuries of $P$. morio parents and rove beetles were also noted. As a control, the number of $P$. morio larvae was also recorded in containers with $P$. morio parents but no rove beetles $(\mathrm{N}=16)$.

\section{RESULTS}

Almost all the fly larvae survived in the control trials. The number of fly larvae that survived in the trial with the male $P$. morio 3-4 h was not significantly different from the control (Fig. 1). In the presence of the male parent there were fewer fly larvae present at the time oviposition occurred (Fig. 1). When the flies were introduced later, the parents were more vigilant, especially the females and the number of fly larvae was significantly reduced (Fig. 1; Holm's method over U-test, $\mathrm{P}<0.05$ ).

\section{Guarding against predators}

No rove beetle predators died in trials without $P$. morio parents, but 6 out of 20 died in the trials with parents present $(P$ $=0.028$, Fisher's Exact test). No P. morio parents were injured in trials with or without rove beetle predators.

When the predator was present, the number of $P$. morio larvae that survived was greater when protected by their parents than when unprotected (Fig. 2; one-way ANOVA, Turky-Krammer method, $\mathrm{F}=20.84, \mathrm{P}<0.0001)$. When protected, the number of $P$. morio larvae that survived was not significantly different from the control (no predator introduced).

\section{DISCUSSION}

Competition between Nicrophorus and carrion flies for carcasses can be intense. Nicrophorus removes fly larvae during carcass maintenance (rolling the carrion ball, treating the carrion with oral and anal secretions) (Pukowski, 1933; Wilson 1983;

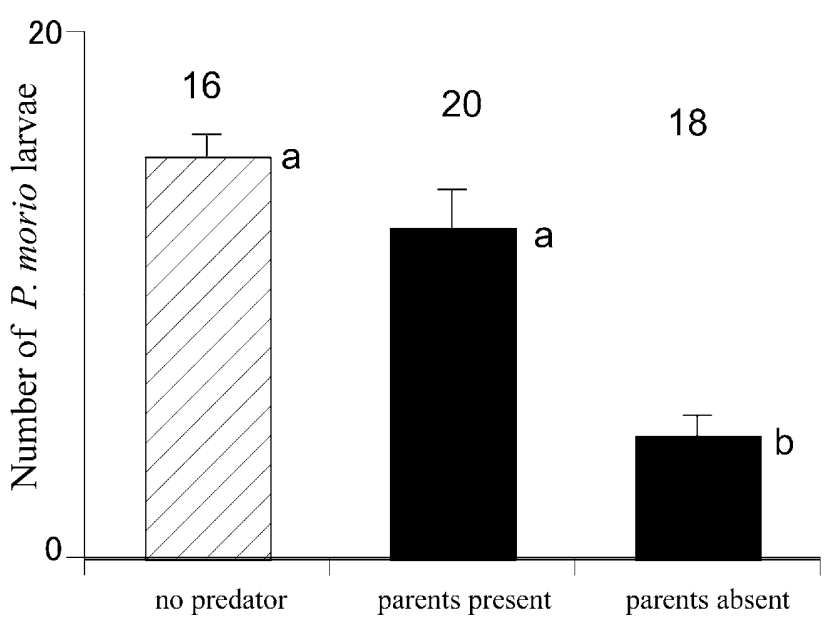

Fig. 2. Mean $( \pm \mathrm{SE})$ number of $P$. morio larvae in the control (no predator, $P$. morio parents present) and in trials with a predator in which the parents were present or absent. Bars with the same letter are not significantly different $(\mathrm{P}<0.01$, TurkyKrammer method).

Wilson \& Knollenberg, 1987; Scott, 1994). Trumbo (1992) recorded that the number and mass of larvae of $N$. orbicollis broods were smaller on fly-infested carcasses than on those not infested with fly larvae. Suzuki (2000) reported that Nicrophorus reduces fly infestation in two ways: carcass burial and carcass maintenance.

Trumbo et al. (2001) found that $P$. morio reduces the negative effects of carrion fly larvae. Since $P$. morio does not bury or maintain carcasses (Peck, 1982; Trumbo et al., 2001), it can only control fly larvae by directly killing them. The present study indicates that this behaviour reduces competition with fly larvae and that female $P$. morio are more effective in this than males. We consider that females may be more effective because they are more often near the carcass after their larvae eclose (Trumbo et al., 2001).

Nicrophorus parents also guard against predators and have been shown to specifically reduce predation by rove beetles (Scott, 1990). Similarly, we found that $P$. morio parents reduced the predation on their brood and in some cases killed the predator. Since P. morio parents had access to a large quantity of carrion in the days before the introduction of the predator, their aggressive behavior is unlikely to be due to hunger. Trumbo et al. (2001) reported that $P$. morio do not protect their brood against predators, but they only used conspecific beetles. Suzuki et al. (2005) also found that P. morio females did not guard against conspecifics. The present study indicates that $P$. morio parents are more aggressive towards heterospecific predators.

The body lengths of $P$. morio and $O$. gracilis are similar. The pronotal widths however, are quite different $(P$. morio mean $=$ $4.3 \mathrm{~mm}$, Nagano \& Suzuki, 2003; O. gracilis mean $=2.9 \mathrm{~mm}$, Suzuki, unpubl. data). The broader $P$. morio may have a distinct advantage in agonistic encounters; no $P$. morio adult were injured in this study, whereas six of 20 rove beetles were killed.

Behavioural studies indicate that female Nicrophorus stay close to their brood after their young hatch (Fetherston et al., 1990; Rauter \& Moore, 2004). A single female is sufficient to protect a brood against predators (Scott, 1990). Since we used a male-female pair of $P$. morio in the predation experiments, the experimental design did not directly compare male versus female defense of the brood. Since females are observed more often near the carcass after the larvae hatch (Trumbo et al., 2001) we suggest that most protection is provided by females. 
Male and female $P$. morio differ in their pattern of association with a carcass; males stay closer to the carcass before and females after the larvae hatch (Trumbo et al., 2001). We have evidence that males stay near and defend the carcass against other males (Suzuki et al., 2005). Since female P. morio are not aggressive to conspecifics (Suzuki et al., 2005), there must be other reasons for females staying close to carcasses, especially after the larvae hatch. Our results suggest that $P$. morio parents reduced both fly competition and predation. We suggest that this behaviour is a simple and possibly primitive form of parental care within the nicrophorines. While the reduction in the number of fly larvae might be attributable to simple predation by $P$. morio, protection of their larvae against predators is clearly parental care. This is the first record of parental care in a silphid other than Nicrophorus.

Competition for resources and predation may be the ecological factors leading to the evolution of parental care (Tallamy \& Wood 1986). "Bonanza" resources, in particular, may promote subsociality (Wilson, 1975). Since Nicrophorinae beetles use small, defendable carcasses as food for their young, selection may favour parental investment. The origin of this parental care has been intensely debated. Most silphid beetles use larger, fly-infested carcasses for reproduction and do not show parental care. Trumbo et al. (2001) suggested that clearing carcasses of fly larvae and emission of a pheromone by males might be early adaptations for exploiting small carcasses. Peck (1982) and Trumbo et al. (2001), however, observed no parental behavior in P. morio. Eggert \& Müller (1997) hypothesized that parental care in Nicrophorus evolved subsequent to the evolution of burying small, manipulable carcasses. Our results indicate that $P$. morio guard small carcass and their broods against both competition from flies and predators, but do not bury carcasses. Since killing fly larvae and defense against predators are also found in Nicrophorus, our study indicates that a prolonged residence time and defense of the carcass and brood are plesiomorphic. These findings provide a new insight into the evolution of parental care in Nicrophorinae beetles.

ACKNOWLEDGEMENTS. We would like to thank S.T. Trumbo for reading the manuscript and making a number of helpful suggestions. This study was supported by a Research Fellowship funded by the Japan Society for the Promotion of Science.

\section{REFERENCES}

Clutton-Brock T.H. 1991: The Evolution of Parental Care. Princeton University Press, Princeton, New Jersey, 352 pp.

Dobler S. \& MÜLler J.K. 2000: Resolving phylogeny at the family level by mitochondrial cytochrome oxidase sequences: Phylogeny of Carrion beetles (Coleoptera: Silphidae). Mol. Phylogen. Evol. 15: 390-402.

EgGERT A.K. \& MÜLLER J.K. 1997: Biparental care and social evolution in burying beetles: lessons from the larder. In Choe J.C. \& Crespi B.J. (eds): The Evolution of Social Behavior in Insects and Arachnids. Cambridge University Press, Cambridge, pp. 216-236.

Fetherston I.A., Scott M.P. \& Traniello J.F.A. 1990: Parental care in burying beetles: the organization of male and female brood care behavior. Ethology 85: 177-190.

HalfFter G. \& EDMONDS W.D. 1982: The Nesting Behavior of Dung Beetles (Scarabaeinae): An Ecological and Evolutionary Approach. Instituto de Ecologia, Mexico City, 176 pp.

Lin C.-P., DANForth B.N. \& Wood T.K. 2004: Molecular phylogenetics and evolution of maternal care in Membracine treehoppers. System. Biol. 3: 400-421.
Nagano M. \& Suzuki S. 2003: Phenology and habitat use among Nicrophorine beetles of the genus Nicrophorus and Ptomascopus (Coleoptera: Silphidae). Edaphologia 73: 1-9.

NaLepa C.A. \& Bell W.J. 1997: Postovulation parental investment and parental care in cockroaches. In Choe J.C. \& Crespi B.J. (eds): The Evolution of Social Behavior in Insects and Arachnids. Cambridge Univ. Press, New York, pp. 26-51.

Ohara M. 1995: Notes on insect fauna of the Nagahashi Naebo area, Otaru, central Hokkaido, Japan, No. 9. Survey of the research in 1992 and 1993, and on the beetles collected by bait trap with dead chicken. Bull. Otaru Mus. 8: 19-42.

PeCK S.B. 1982: The life history of the Japanese carrion beetle Ptomascopus morio and the origins of parental care in Nicrophorus (Coleoptera, Silphidae, Nicrophorini). Psyche 89: 107-111.

Peck S.B. \& Anderson R.S. 1985: Taxonomy, phylogeny, and biogeography of the carrion beetles of Latin America (Coleoptera: Silphidae). Quaest. Entomol. 21: 247-317.

Pukowski E. 1933: Ökologische Untersuchungen an Necrophorus F. Z. Morphol. Oekol. Tiere 27: 518-586.

RAUTER C.M. \& Moore A.J. 2004: Time constraints and tradeoffs among parental care behaviours: effects of brood size, sex and loss of mate. Anim. Behav. 68: 695-702.

Sсотт M.P. 1990: Brood guarding and the evolution of male parental care in burying beetles. Behav. Ecol. Sociobiol. 26: 31-39.

ScotT M.P. 1994: Competition with flies promotes communal breeding in burying beetle, Nicrophorus tomentosus. Behav. Ecol. Sociobiol. 34: 367-373.

Sсотт M.P. 1998: The ecology and behavior of burying beetles. Annu. Rev. Entomol. 43: 595-618.

SUZUKI S. 2000: Carrion burial by Nicrophorus vespilloides (Coleoptera: Silphidae) prevents fly infestation. Entomol. Sci. 3: 269-273.

Suzuki S., Nagano M. \& Trumbo S.T. 2005: Intrasexual competition and mating behavior in Ptomascopus morio (Coleoptera: Silphidae: Nicrophorinae) J. Insect Behav. 18: 233-242.

Szalanski A.L., Sikes D.S., Bischof R. \& Fritz M. 2000: Population genetics and phylogenetics of the endangered American burying beetle, Nicrophorus americanus (Coleoptera: Silphidae). Ann. Entomol. Soc Am. 93: 589-594.

Tallamy D.W. 1994: Nourishment and the evolution of parental investment in subsocial arthropods. In Hunt J.H. \& Nalepa C.A. (eds): Nourishment and Evolution in Insect Societies. Westview Press, Boulder, pp. 21-55.

Tallamy D.W. 1999: Child care among the insects. Sci. Am. 280: $72-77$.

Tallamy D.W. \& Schaefer C. 1997: Maternal care in the Hemiptera: ancestry, alternatives, and current adaptive value. In Choe J.C. \& Crespi B.J. (eds): The Evolution of Social Behavior in Insects and Arachnids. Cambridge Univ. Press, New York, pp. 94-115.

Tallamy D.W. \& Wood T.K. 1986: Convergence patterns in subsocial insects. Annu. Rev. Entomol. 31: 369-390.

TRUMBo S.T. 1992: Monogamy to communal breeding: exploitation of a broad resource base by burying beetles (Nicrophorus). Ecol. Entomol. 17: 289-298.

Trumbo S.T., Kon M. \& Sikes D.S. 2001: The reproductive biology of Ptomascopus morio, a brood parasite of Nicrophorus. J. Zool. (Lond.) 255: 543-560.

WILSON D.S. 1983: The effect of population structure on the evolution of mutualism: a field test involving burying beetles and their phoretic mites. Am. Nat. 121: 851-870. 
Wilson D.S. \& KNollenberg W.G. 1987: Adaptive indirect effects: the fitness of burying beetles with and without their phoretic mites. Evol. Ecol. 1: 139-159.

Wilson E.O. 1971: The Insect Societies. Belknap Press, Harvard University, Cambridge, 548 pp.
WILSON E.O. 1975: Sociobiology. The New Synthesis. Belknap Press, Harvard University, Cambridge, 697 pp.

Received May 6, 2005; revised and accepted July 13, 2005 